\title{
The Starting Age and Ultimate Attainment of English Learning in the Palestinian Context
}

\author{
Raghad Dwaik $^{1} \&$ Adnan Shehadeh ${ }^{2}$ \\ ${ }^{1}$ English Department, Hebron University, Hebron, Palestine \\ ${ }^{2}$ Language Center, Palestine Polytechnic University, Hebron, Palestine \\ Correspondence: Raghad Dwaik, English Department, Hebron University, Hebron, Palestine. Tel: \\ 972-597-443-414. E-mail: raghaddwaik@yahoo.com
}

\author{
Received: August 2, 2015 Accepted: September 6, 2015 Online Published: September 9, 2015 \\ doi:10.5539/elt.v8n10p91 URL: http://dx.doi.org/10.5539/elt.v8n10p91
}

\begin{abstract}
The starting age of foreign language learning has been a controversial issue since the second half of the $20^{\text {th }}$ century. Despite this long time, definite answers have not been found regarding the different aspects of the age issue, i.e., its influence on rate, route and ultimate attainment. Many researchers have explored the influence of age on the rate of language acquisition, its route and the level of ultimate attainment reached by the students. This study explores the third dimension, i.e., the level of ultimate attainment and compares this dimension between a group of students who started learning English from the first grade and another group which started learning English in the fifth grade, i.e., around the onset time of puberty. 1846 students participated in the study and the percentage of females among them was $40 \%$. All participants sat for an English test that measured their competence in reading, writing, speaking, and listening as well as grammar and vocabulary. Results show that first grade starters had a significant advantage over fifth grade starters only in vocabulary and reading comprehension. As for grammar and writing, no significant differences were found between the two groups, yet a higher mean was achieved by the late starters. When it comes to the aural-oral skills (listening and speaking), no significant differences were detected between the two groups. It was noticed, however, that the mean of the fifth grade starters was slightly higher in the listening skill while the mean of the first grade starters was higher in speaking.
\end{abstract}

Keywords: age factor in EFL, young learners, early start English programs, individual learner differences, language planning in Palestine

\section{Introduction}

The Critical Period Hypothesis in language learning was first proposed by Penfield and Roberts (1959), and then it was developed for second language acquisition by Lenneberg in 1967. According to this theory, it is argued that there is a time period when language learning may take place in a natural way and without much effort. After that age period, learners face increasing difficulty in language learning and may be unable to attain native like proficiency in many aspects of language especially pronunciation (Ellis, 1999). Older learners, however, were noted to progress faster in language learning due to their cognitive maturity. Those conflicting findings have urged researchers to analyze the influence of the age variable on language learning along three axes: rate, route and ultimate attainment, i.e., long term learning to get a more comprehensive perspective.

Some researchers strongly argue that children who start learning a foreign or second language earlier may achieve higher levels of proficiency than those starting later (Oyama, 1976; Coppiters, 1987; Patkowski, 1980). These findings are supported by Long (1990) who synthesized previous research on the age issue and came up with several conclusions. His first observation was that both rate and ultimate attainment are influenced by the starting age. A second conclusion was that in both first and second language acquisition there is a sensitive period during which language learning is easiest (Critical period). A third conclusion was that the deterioration of language acquisition with age was cumulative and did not happen at a specific point in time, yet, in some learners it may start as early as the age of six. Researchers such as Patkowski (1980) even found that children 
who started learning grammar before the age of fifteen reached higher levels of syntactic proficiency than those who started after that age. Support for the critical period is also clear in the work of Christine Weber-Fox and Helen Neville (1999) that investigated Event Related Brain Potentials (EPR) among bilinguals and found that the brain activity among late bilinguals showed different patterns comparing to those of early bilinguals. They noticed different processing of grammatical aspects among members of both groups.

Research stemming from the critical period hypothesis shows that there is clear evidence in favor of early language learners and those children surpass both adolescents and adults in language acquisition.

Some researchers expressed clear reservation with regard to the Critical Period Hypothesis including Ellis (1985) who argued that the only advantage that young starters enjoy is in the acquisition of pronunciation. Recent neurological research has also showed that the exact age at which lateralization may take place is not definite yet. Gui Shicun (1992) argues that since we cannot get a definite answer regarding the best age for language learning, one should work on studying the features of each age group and finding methods, techniques and activities that suit each of them. Dai Weidong (2008), found that the starting age for language learning is unimportant and the most important factor is the amount of time learners invest in learning itself.

In the Palestinian context, English started to be taught from the first grade and, in some cases, from the kindergarten since the year 2000. From that year on, little formal research has been conducted to measure the influence of such a step on the students' proficiency or on their ultimate attainment in the English language although those young starters have already finished school and joined college. This paper is an attempt to shed some light on the age issue in language learning by comparing the level that students who have started learning English from the first grade have to the level attained by those who started from the fifth grade.

Dekeyser, Alfi-Shabati and Ravid (2010) argue that the starting age is a crucial factor in determining the level of ultimate attainment in L2 proficiency. Many researchers have corroborated this view arguing that it is not a matter of a biologically determined period as was claimed by the early researchers, rather it is a general decline in cognitive abilities and change in modes of socialization that naturally occur as a result of age progression (Bialystok \& Hakuta, 1999; Bialystok \& Miller, 1999; Hakuta, Bialystok, \& Wiley, 2003).

One may hence argue that researchers with different orientations and perspectives agree that there is a negative correlation between the starting age of acquisition and the ultimate attainment achieved. They, disagree, however, on whether the cause of such variation is biological (i.e., the critical period hypothesis) on the one hand or cognitive and social on the other.

One may also note that such studies on the correlation between the starting age and ultimate attainment have been conducted on immigrants in second language settings thus leaving foreign language setting without much quantitative evidence to inform and support decision making (Dekeyser, Alfi-Shabati, \& Ravid, 2010). Moreover, studies that were conducted on immigrants suffer from a number of methodological problems including sample size (around 50 participants), and narrow focus, e.g., stressing grammatical competence over other language skills.

A number of recommendations have been made by some researchers in order to reach more conclusive evidence regarding the age issue in general and the critical period hypothesis in particular. These recommendations include increasing the sample size and conducting research on differentiated language competencies (e.g., grammar, vocabulary, and pronunciation, etc). They also argue that research should add qualitative aspects and should be carried out on cross linguistic levels. In other words, it should check the ultimate attainment of learners from similar L1 backgrounds learning different L2s or vice versa, i.e, those with different linguistic backgrounds learning the same L2 (Dekeyser, Alfi-Shabati \& Ravid, 2010).

\section{Literature Review}

Advocating early start English programs in the 1950s and 60s was largely influenced by research on the critical period hypothesis conducted by Pendfield and Roberts (1959). Those studies emphasized the "earlier is better" argument based on the assumption that the brain loses its elasticity or ability to establish new connections between neural cells around the age of puberty.

This early start advantage was corroborated by research on immigrant learners conducted in the context of naturalistic settings in the 1970s and 80s (Johson \& Newport, 1989; Hyltenstam, 1992; Krashen, Long, \& Scarcella, 1979; Oyama, 1976, 1978; Patkowski, 1980; Snow \& Hoefnagel-Hohle, 1978). Studies in this context show that the earlier a child immigrant is exposed to the target language the higher proficiency he eventually 
attains in that language. As for older learners who enjoy the advantage of higher cognitive development, they show initial advantage only in the rate of target language acquisition. In other words, the initial advantage of older learners is outweighed by the ultimate attainment achieved by early starters in these naturalistic settings.

Results of studies on learners in naturalistic settings were often mistakenly generalized to the foreign language environment (Dekeyser, 2000; Dekeyser \& Larson-Hall, 2005; Patkowski, 994). Many researchers, however, have found that in the classroom context, older learners show a clear advantage when it comes to the rate of acquisition; yet younger ones do not surpass them in terms of the ultimate attainment (Alveraz, 2006; Cenoz, 2002, 2003; Kalbere, 2007; Mora, 2006; Munoz, 2003). This is especially true when the younger beginners are exposed to a similar number of instructional hours as the older ones (Munoz, 2006, 2008; Naves, 2009).

Munoz (2006) argues that incidental or implicit language acquisition takes place only when the young learner is exposed to extensive input over a long period of time as in the case of naturalistic settings. Such "massive" input is not readily available in typical formal classroom settings. Older beginners, however, are at an advantage since they can easily make use of their sophisticated cognitive development to make the best out of their learning experience inside the classroom. Singleton and Skrzypek (2014) argue that comparing younger and older beginners in second language ultimate attainment should not take place till both groups have reached their "end state" or "asymptote", i.e., the stage after which additional development is not expected.

An additional insight could be gained from the argument of Singleton and Skrzypek (2014) who referred to an earlier study in the Irish context where an early start was counted on to make up for drawbacks in the educational context itself. Results of that study showed that starting earlier will not help the learners overcome negative variables in their learning environment such as lack of facilities, poor teaching methods, or a negative attitude.

\section{Purpose of the Study}

The purpose of this study is to investigate the effect of the starting age of English learning on the students' general or ultimate attainment in English as a foreign language as measured by the College English Placement Test (CEPT) and by an additional test designed and validated by the researchers and a panel of English teachers. The study also examines the effect of the early start on the students' performance in the required English courses at the College level. This general achievement is measured along different dimensions: reading, writing, listening, speaking as well as the constructs of vocabulary and grammar.

\section{Research Questions}

The study investigates whether the starting age influences the ultimate attainment in the four language skills as well as vocabulary and grammar. This issue is broken down into a number of research questions:

1) To what extent does the starting age influence the students' attainment in the oral-aural skills (listening and speaking)?

2) To what extent does the staring age influence the students' attainment in the literacy skills, i.e., reading and writing?

3) To what extent does the starting age influence the students' attainment in vocabulary and grammar?

4) To what extent does the starting age predict the students' performance in the required English courses at the college level?

\section{Methodology}

\subsection{Sample of the Study}

The sample of this study consists of 1846 freshman college students. 940 of these students started learning English from the first grade while the other 906 started in the $5^{\text {th }}$ grade. The percentage of females was approximately $40 \%$. All participants in the study are graduates of the Palestinian public school system. Their chosen fields of study include engineering, applied and administrative sciences, as well as computer engineering and information technology (IT). 
The following table contains a breakdown of the study sample according to the year they started learning English and across the four language skills as well as vocabulary and grammar.

\begin{tabular}{|c|c|c|c|c|c|c|c|c|c|c|c|c|}
\hline & \multicolumn{2}{|c|}{ Listening } & \multicolumn{2}{|c|}{ Speaking } & \multicolumn{2}{|c|}{ Reading } & \multicolumn{2}{|c|}{ Writing } & \multicolumn{2}{|c|}{ Vocabulary } & \multicolumn{2}{|c|}{ Grammar } \\
\hline & $\mathrm{M}$ & $\mathrm{F}$ & $\mathrm{M}$ & $\mathrm{F}$ & $\mathrm{M}$ & $\mathrm{F}$ & $\mathrm{M}$ & $\mathrm{F}$ & $\mathrm{M}$ & $\mathrm{F}$ & $\mathrm{M}$ & $\mathrm{F}$ \\
\hline First Grade starters & 104 & 91 & 22 & 18 & 522 & 418 & 85 & 80 & 522 & 418 & 522 & 418 \\
\hline Total & 195 & & 40 & & 940 & & 170 & & 940 & & 940 & \\
\hline Fifth Grade starters & 143 & 110 & 22 & 18 & 504 & 402 & 113 & 100 & 504 & 402 & 504 & 402 \\
\hline Total & 253 & & 40 & & 906 & & 213 & & 906 & & 906 & \\
\hline Total & 448 & & 80 & & 1846 & & 378 & & 1846 & & 1846 & \\
\hline
\end{tabular}

\subsection{Instruments, Procedures and Data Collection}

Different instruments have been used to measure achievement in the different language skills and constructs.

For reading, vocabulary, and grammar, the researchers used the results of the placement test implemented at Palestine Polytechnic University (PPU) at the start of the academic year 2011/2012. This is a computer based test that lasts for 90 minutes. The test is based on a question bank that contains 100 multiple choice grammatical points, 20 reading passages taken from the Test of English as a Foreign Language (TOEFL) practice materials and 50 multiple choice vocabulary items. The computer is programmed to download two random reading passages for every test taker. Vocabulary and grammar are also chosen randomly from the question bank for every participant. As for writing, 378 students were selected to participate in the test 170 ( 80 females) of these student s were first grade starters while 213 (100 females) were fifth grade starters. The selected sample reflected the different levels of the students (beginner, intermediate, advanced). These three levels were classified according to their grades in the placement test. Each student was then asked to write two five paragraph essays about two different topics. In the first topic, students were asked to respond to a question that probes whether it is better to live in a big or a small family and to support their answers with examples. As for the second topic they were asked to comment on the issue of college education and whether it should be supported by the government or by the individual's family. To enhance test reliability, students were given some starter ideas to help them conceptualize their own thoughts and positions. The passages were then given to two school teachers who were provided with general criteria for corrections. The average grade was taken for each participant.

In listening, the participants were exposed to 50 short conversations (similar to those used in the TOEFL practice tests). Each conversation was followed by a multiple choice question based on general comprehension or inference. About 446 students participated in this part of the test. 195 of these students were first grade starters and 258 were fifth grade starters.

As for speaking, 80 participants were asked to sit for an oral interview that took into account the Oral proficiency Interview (OPI) guidelines. Forty of these students were first grade starters while the other 40 were fifth grade starters. The interviews were recorded and evaluated by two teachers then the researchers took the average grade. The first part of the test focused on general information related to familiar topics from the participants' everyday life, then the participant is asked to talk at length about a certain theme then he/she would be involved in a two way interaction with the examiner.

\section{Results and Discussion}

Results of this study will be presented in the order of the research questions.

\subsection{Question One}

To what extent does the starting age influence the students' ultimate attainment in the oral-aural (speaking and listening) skills?

Although there were no significant differences at $\alpha=.05$ between the first and the fifth grade starters in terms of listening and speaking $(\mathrm{p}=0.098)$, there was a slight difference in their means in favor of the fifth grade starters. Table one below shows that the mean for the fifth grade starters in listening was 16.11 while for the first grade 
starters, it was 15.55 . As for speaking, there were not any significant differences between the two groups either. There was a slight difference though in favor of the first grade starters. The mean for the first grade starters was 5.20 while it was 5.15 for the fifth grade starters. The listening and speaking results are rather surprising taking into account that first grade starters were exposed to 256 extra instruction hours during the first four years of EFL instruction. These hours were accumulated over a period of four years during which they were exposed to three English lessons per week. Each of these lessons normally lasted for forty minutes. This result might be due to the unavailability of cd-players, tape recorders or any other listening devices at some schools or to the fact that teachers tend to focus on reading, writing and grammar in their instruction because these skills are the ones underscored in the high school exit exam and other general tests.

Table 1. Means, standard deviations and the t-value for the results of both groups in listening and speaking

\begin{tabular}{lllllllll}
\hline Skill & Starting Grade & $\mathrm{N}$ & Mean & Std. Dev. & Maximum & Std. Error Mean & t. & P. \\
\hline Listening & First & 195 & 15.5590 & 9.298 & 50 & .66589 & -0.665 & 0.506 \\
& Fifth & 253 & 16.1107 & 8.215 & & .51648 & & \\
\multirow{2}{*}{ Speaking } & First & 40 & 5.20 & 1.19 & 10 & 1.19 & 0.159 & 0.875 \\
& Fifth & 40 & 5.15 & .74 & & 0.74 & & \\
\hline
\end{tabular}

\subsection{Question Two}

To what extent does the starting age influence the students' attainment in the literacy skills, i.e., reading and writing?

Results of this study show that there are no significant differences between first and fifth grade starters in terms of the ultimate attainment of the writing skill. Table two below shows a slight difference in the mean of both groups. The mean for the first grade starters was 10.31 while that of the fifth grade starters was 10.79. Again, one may easily notice that although there was no significant difference between both groups, yet the mean for the later starters was slightly higher.

Table 2. Means, standard deviations and the t-value for the results of both groups in reading and writing

\begin{tabular}{llllllll}
\hline Skill & Starting Grade & N & Mean & Max. & Std. Dev. & T. & P. \\
\hline Reading & First & 908 & 7.47 & 20 & 3.10 & -3.20 & .001 \\
& Fifth & 940 & 7.00 & & 3.29 & & \\
\multirow{2}{*}{ Writing } & First & 213 & 10.31 & 20 & 3.48 & 1.29 & .197 \\
& Fifth & 165 & 10.79 & & 3.72 & & \\
\hline
\end{tabular}

As for the ultimate attainment of reading, results show a significant difference in favor of the first grade starters $(p=.001)$. Table two above shows that the mean for the first grade starters was 7.47 while that for the fifth grade starters was 7.00 .

Unlike listening and writing where results were in favor of the later starters (fifth grade), results of reading show some advantage for early starters. This might be due to the fact that English teachers in general tend to stress the literacy skills in their instruction because these skills are the ones focused upon in all types of general exams. In other words, the extra instruction hours (estimated around 256) were really translated into higher level of reading acquisition.

\subsection{Question Three}

To what extent does the starting age influence the students' attainment in vocabulary and grammar?

Results show that there are significant differences in the ultimate attainment of vocabulary in favor of the first grade starters $(\mathrm{p}=.000)$. Table three below shows that these early starters had an advantage in the ultimate attainment of vocabulary $(\mathrm{M}=4.39)$ while the mean of the fifth graders was 3.04. One may argue that this result 
is related to the students' results in reading comprehension which also showed an advantage for early starters. In other words, the students benefited from the additional instructional hours in the case of reading comprehension and an integral construct of it which is vocabulary development. Research has also shown that extensive exposure to reading texts leads to incidental vocabulary learning. Over 12 years of exposure to the language, students definitely enjoyed repetitive exposure and practice of plenty of vocabulary items in different topics and contexts especially that the reading passage are the backbone of all units in the English for Palestine syllabus.

As for grammar, significant differences were detected in favor of the fifth grade starters $(p=.000)$. This is also connected to the results of both groups in the ultimate attainment of the writing skill. Table three below shows that the mean for the fifth grade starters was 8.15 while for the first grade starters, it was 6.77 . This might be due to the fact that grammar instruction is not focused upon in the text or by teachers during the first 4 years of schooling. It might also be due to the fact that late starters generally enjoy a higher level of cognitive maturity which generally helps them in internalizing rules of an abstract nature. Fifth grade starters may also have benefited from the syllabus they used which emphasized a more structural orientation to language instruction.

Table 3. Means, standard deviations and the t-value for the results of both groups in vocabulary and grammar

\begin{tabular}{llllllll}
\hline Skill & Starting Grade & N & Mean & Max. & Std. Dev. & T. & P. \\
\hline Vocabulary & First & 940 & 4.39 & 10 & 2.98 & 11.523 & .000 \\
& Fifth & 906 & 3.04 & & 1.87 & & \\
\multirow{3}{*}{ Grammar } & First & 940 & 6.77 & 20 & 3.47 & -9.159 & .000 \\
& Fifth & 908 & 8.15 & & 3.01 & & \\
\hline
\end{tabular}

\subsection{Question Four}

To what extent does the starting age predict the students' performance in the required English courses at the college level?

This study also probed the influence of the starting age on the performance of both groups in one of their English courses at the college level. This course is a freshman level university requirement taught at Palestine Polytechnic University. The emphasis of this course is reading comprehension and it is usually tested through exams that probe students' reading achievement and vocabulary attainment. Probing the influence of an early start on the students' performance in this course is of high importance because it highlights the utility of early start programs for fulfilling the learner needs in achieving real life purposes. Achievement of these purposes is generally seen as the ultimate goal of language acquisition and learning. It is also important in light of the Palestinian curriculum guidelines which stress the importance of EFL instruction as a tool to cope with future college requirements, especially that English is the language of instruction in most colleges particularly the scientific ones.

Table four below shows that there are no significant differences between first grade starters and those who started in the fifth grade $(\mathrm{p}=0.827)$. One may also notice a slight difference in means in favor of the early starters $\left(\mathrm{M}=69.52\right.$ for $1^{\text {st }}$ grade, and $\mathrm{M}=69.43$ for the fifth) yet this difference did not hit the significance threshold.

Table 4. Means, standard deviations and the t-value for the results of both groups in the English One course

\begin{tabular}{llllllll}
\hline English course & Starting Grade & $\mathrm{N}$ & Mean & Max. & Std. Dev. & T. & P. \\
\hline English One & First & 949 & 69.52 & 100 & 9.31 & -0.218 & 0.827 \\
& Fifth & 975 & 69.43 & & 9.35 & & \\
\hline
\end{tabular}

\section{Conclusion}

Results of this study have shown that there are no significant differences between first and fifth grade starters except in one skill which is reading and one language construct which is vocabulary, which is usually considered a sub skill of reading. This may be contrasted by the results of a short term study conducted earlier by the same 
researchers (Shehadeh \& Dwaik, 2010) and showing a clear advantage for fifth grade starters in vocabulary and reading. The advantage for first grade starters reflected in this study show that the additional instruction hours, estimated at 256 have actually resulted in some benefit for early starters as originally conceptualized by policy makers and planned by the curriculum developers. This advantage, however, did not translate into a better ability to deal with college courses, i.e., they were not predictive of the same students performance in English college course which may be considered as the ultimate aim and the real life need of the students involved in this study. Further research is needed to throw more light on this discrepancy and to analyze reasons behind the failure of the students' enhanced competence in fulfilling their needs or achieving real life purposes. Research is also needed to probe whether exposing students to additional instructional hours would be more beneficial had it occurred later during their school years, i.e., during high primary or secondary stage for instance.

Results also show that the additional 256 hours of instruction did not result in any significant advantage for the first grade starters in listening, speaking, grammar and writing. Extensive research is needed in the future to find reasons behind that. The researchers however, believe that traditional instructional methods and negative backwash from standardized tests such as the Tawjihi (the High school exit exam) may have led to ignoring the proper instruction of vital language skills such as listening and speaking. Teachers for example have reported earlier that listening equipment are not available at some schools and that the listening text is sometimes read aloud by the teachers themselves to make up for the lack of equipment (Shehadeh \& Dwaik, 2010). The Tawjihi test also completely ignores the oral-aural skills and tests only the literacy skills, i.e., reading and writing as well as vocabulary and grammar. This makes English teachers pay less attention to the skills that are not tested in this exam, namely, listening and speaking.

Results also show that the student means are generally very low across all skills regardless of their English learning starting age. The highest mean was obtained in the writing skill $(M=10.79 \backslash 20$ i.e., 27/50). The lowest mean in all skills and constructs was obtained in listening $(\mathrm{M}=15.55 \backslash 50)$. This is a disappointing result taking into account that these students have studied English for 8-12 years. Not only that but also they have all passed the Tawjihi exam with a general average of $76 \%$ and a minimum grade of $65 \%$ according to the university records. One may hence argue that weakness in English is not an issue of the starting age; rather it is a matter of a combination of factors that need to be carefully studied and analyzed to reach valid and reliable conclusions regarding the future of English teaching in Palestine in particular and in the Arab World in general. The budgets invested in early start programs could be better utilized by conducting such research that would improve the general outcomes of teaching English as a foreign language is the whole region.

\section{References}

Alvarez, E. (2006). Rate and route of acquisition in EFL narrative development at different ages. In C. Munoz (Ed.), Age and the Rate of Foreign Language Learning (pp. 127-155). Clevedon: Multilingual Matters.

Bialystok, E., \& Hakuta, K. (1999). Confounded age: Linguistic and cognitive factors in age differences for second language acquisition. In D. Birdsong (Ed.), Second language acquisition and the critical period hypothesis (pp. 161-181). Mahwah, NJ: Erlbaum.

Bialystok, E., \& Miller, B. (1999). The problem of age in second language acquisition: Influences from language, task, and structure. Bilingualism: Language and Cognition, 2, 127-145. http://dx.doi.org/10.1017/S1366728999000231

Cenoz, J. (2002). Age differences in foreign language learning. I.T.L. Review of Applied Linguistics, 135-136, 125-142.

Coppieters, R. (1987). Competence differences between native and near-native speakers. Lg., 63, 544-73. http://dx.doi.org/10.2307/415005

Dai, W., \& Wei, L. (2008). The Study of Chinese Learners' Acquisition of English Article Semantic Features. Foreign Language Teaching and Research, 40(2), 136-142.

Dekeyser, R, Alfa-Shabatay, I., \& Ravid, D. (2010). Cross- linguistic evidence for the nature of age effects in second language acquisition. Applied Psycholinguistics, 31, 413-438. http://dx.doi.org/10.1017/S0142716410000056

Dekeyser, R. (2000). The robustness of critical period effects in second language acquisition. Studies in Second Language Acquisition, 22(4), 499-534. 
Dekeyser, R., \& Larson-Hall, J. (2005). What does the critical period really mean? In J. F. Kroll, \& A. De Groot (Eeds.). Handbook of bilingualism: Psycholingistic approaches (pp. 88-108). Oxford: Oxford University Press.

Dwaik, R., \& Shehadeh, A. (2010). Motivation types among EFL college students:Insights from the Palestinian context. An-Najah University Journal of Humanities, 24(1), 333-360.

Ellis, R. (1985). Understanding second language acquisition. Oxford: Oxford University Press.

Ellis, R. (1999). Making the classroom acquisition-rich. In R. Ellis (Ed.), Learning a second language through interaction (pp. 211-229). Amsterdam: John Benjamins. http://dx.doi.org/10.1075/sibil.17

Gui, S. (1992). Doubt on foreign language learning must be started from an earlier age. Foreign Language Teaching and Research, 4, 52-54.

Hakuta, K., Bialystok, E., \& Wiley, E. (2003). Critical evidence: A test of the critical period hypothesis for second language acquisition. Psychological Science, 14, 31-38. http://dx.doi.org/10.1111/1467-9280.01415

Hyltenstam, K. (1992). Non-native features of near-native speakers: on the ultimate attainment of childhood L2 learners. In R. Harris (Ed.). Cognitive Processing in Bilinguals (pp. 351-368). Amsterdam: Elsevier Science. http://dx.doi.org/10.1016/S0166-4115(08)61505-8

Johnson, J. S., \& Newport, E. L. (1989). Critical period effects in second language learning: The influence of maturational state on the acquisition of English as a second language. Cognitive Psychology, 21, 60-99. http://dx.doi.org/10.1016/0010-0285(89)90003-0

Kalberer, U. (2007). Rate of L2 acquisition and the influence of instruction time on achievement. Unpublished Master of Education Thesis, University of Manchester.

Krashen, S. D., Long, M. A., \& Scarcella, R. C. (1979). Age, rate and eventual attainment in second language acquisition. TESOL Quarterly, 13, 573-82. http://dx.doi.org/10.2307/3586451

Lenneberg, E. H. (1967). Biological Foundations of Language. New York, NY: Wiley.

Long, M. H. (1996). The role of the linguistic environment in second language acquisition. In W. Ritchie, \& T. Bhatia (Eds.), Handbook of second language acquisition (pp. 413-468). New York: Academic Press. http://dx.doi.org/10.1016/b978-012589042-7/50015-3

Muñoz, C. (2003). Variation in oral skills development and age of onset. In M. P. G. Mayo, \& M. L. G. Lecumberri (Eds.), Age and the acquisition of English as a foreign language (pp. 161-181). Clevedon: Multilingual Matters Ltd.

Munoz, C. (2006). Age and the Rate of Foreign Language Learning. Clevedon: Multilingual Matters.

Munoz, C. (2008). Symmetries and asymmetries of age effects in natrualiatic and instructed L2 learning. Applied Linguistics, 24(4), 578-596. http://dx.doi.org/10.1093/applin/amm056

Navés, T. (2006). The long-term effects of an early start on foreign language writing. Unpublished Doctoral Dissertation, University of Barcelona.

Oyama, S. (1976). A sensitive period for the acquisition of a nonnative phonological system. Journal of Psycholinguistic Research, 5, 261-283. http://dx.doi.org/10.1007/BF01067377

Patkowski, M. (1994). The critical age hypothesis and interlanguage phonology. In M. Yavas (Ed.), First and second language phonology (pp. 205-221). San Diego, CA: Singular Publishing Group.

Patkowski, M. S. (1980). The sensitive period for the acquisition of syntax in a second language. Language Learning, 30, 449-72. http://dx.doi.org/10.1111/j.1467-1770.1980.tb00328.x

Penfield, W., \& Roberts, L. (1959). Speech and brain mechanisms. Princeton, NJ: Princeton University Press.

Shehadeh, A., \& Dwaik, R. (2010). The age factor in EFL learning: Insights from the Palestinian early start English program. An-Najah University Journal of Humanities, 24(7), 2119-2149.

Shehadeh, A., \& Dwaik, R. (2013). The practice of teaching English to young learners in the Palestinian context: a multidimensional analysis. AWEJ, 4(3) 63-76.

Singleton, D., \& Skrzypek, A. (2014). Age and the classroom learning of additional languages. In M. Pawlak, J. Bielak, \& A. Mystkowska-Wiertelak (Eds.), Classroom-oriented research: Achievements and challenges 
(pp. 3-13). Heldelberg: Springer. http://dx.doi.org/10.1007/978-3-319-00188-3_1

Snow, C. E., \& Hoefnagel-Hohle, M. (1978). The critical period for language acquisition: Evidence from second language learning. Child Development, 49, 1114-1128. http://dx.doi.org/10.2307/1128751

Weber-Fox, C., \& Neville, H. (1999). Functional Neural Subsystems are Differentially Affected by Delays in Second Language Immersion: ERP and Behavioral Evidence in Bilinguals. In D. Birdsong (Ed.) Second Language Acquisition and the Critical Period Hypothesis (pp. 23-38). Lawrence Erlbaum Publishers.

\section{Copyrights}

Copyright for this article is retained by the author(s), with first publication rights granted to the journal.

This is an open-access article distributed under the terms and conditions of the Creative Commons Attribution license (http://creativecommons.org/licenses/by/3.0/). 